\title{
PLUM CULTIVARS IN SWEDEN: HISTORY AND CONSERVATION FOR FUTURE USE
}

\author{
Inger Hjalmarsson \\ Department of Landscape Architecture, Planning and Management, Swedish University of Agricultural Sciences, \\ PO Box 57, SE-230 53, Alnarp, SWEDEN \\ Corresponding author, inger.hjalmarsson@slu.se
}

Communicated by Gunārs Lācis

\begin{abstract}
This article reviews the history of plum cultivation and cultivars in Sweden with the aim to describe important heirloom cultivars and to explain how they are conserved in the Swedish $\mathrm{Na}$ tional Gene Bank. Commercial plum production in Sweden started around 1890 and was initially in part based on small-fruited local cultivars grown on their own roots. Along with the development of a modern Swedish nursery industry and experimental research the use of grafted trees grew in importance. In the mid-1950s, the yearly plum production in Sweden was estimated to be approximately 2000 tonnes. Since the mid-1980s, production has declined and it is now only about 250 tonnes per year. The work to safeguard heirloom cultivars began with a national inventory in 2005 and since 2012, so-called mandate cultivars have been planted in the Swedish National Gene Bank at Alnarp. Today 45 plum cultivars are preserved with two trees in the gene bank at Alnarp and two trees in local clonal archives.
\end{abstract}

Key words: Prunus domestica, plum cultivation, heirloom cultivars, gene bank, genetic resources.

\section{INTRODUCTION}

It is believed that the European plum Prunus domestica $\mathrm{L}$. $(2 \mathrm{n}=48)$ developed through a hybridisation between cherry plum $P$. cerasifera Ehrh. $(2 \mathrm{n}=16)$ and sloe $P$. spinosa $\mathrm{L}$. $(2 \mathrm{n}=32)$ involving a spontaneous doubling of the resulting sterile triploid (Westwood, 1993; Anderberg and Anderberg, 2017). The small fruited damson plum $P$. domestica ssp. insititia (L.) Poir, is considered to have the same background as the European plum and may cross with this species. Most likely plums were not cultivated in Scandinavia until the arrival of Christianity when monks planted damson plums in monastic gardens (Nilsson, 1989). The existence of damson plums in Sweden during the Middles Ages has been confirmed by finds of plum stones during archaeological excavations (Hjelmqvist, 1991). Propagation of damson plums by rootlets was easy and thus the cultivation also spread outside of the monasteries. Some of the oldest still existing cultivars grown on their own roots could be remnant from medieval times.

Records from noble estates show that the first attempt to import large fruited plum cultivars to Sweden probably took place at the turn of the $16^{\text {th }} / 17^{\text {th }}$ centuries. As reported by
Hjalmarsson et al. (2008), the first attempt to systematically describe and classify plum cultivars grown in Sweden was made by Eneroth, who published his pomology in 1866 . This was followed by a revised edition at the turn of the century (Eneroth and Smirnoff, 1901). The next Swedish pomology was written by Dahl, who added plums to his second edition published in 1943. In 1989, a new pomology including plums was published by Nilsson. In addition, the rather magnificent work of Pihl and Eriksson (1912) among other fruits portrayed 15 plum cultivars in coloured plates.

For the National Programme for Diversity of Cultivated Plants (Pom), which started its activities in 2000, it was important to select and recover old plum cultivars of Swedish origin as well as foreign cultivars with a long Swedish growing tradition. Initially 41 cultivars were selected as socalled mandate cultivars intended for long time conservation in the Swedish National Gene Bank (Hjalmarsson, 2007). After a national inventory conducted by Pom, the list changed slightly due to some interesting finds, and at the moment it comprises 45 cultivars, including the Swedish bred rootstock 'Eruni'. The planting of these cultivars in the Swedish National Gene Bank will be finalised in the near future. 
PLUM CULTIVARS AND CULTIVATION DURING THE $18^{\mathrm{TH}}$ AND $19^{\mathrm{TH}}$ CENTURIES

During the $18^{\text {th }}$ century, small fruited plums on their own roots, like damson plums and the white-yellow fruited cultivar 'Allmänt Gulplommon' ('Ordinary Yellow Plum', Fig. 1 ), were the most commonly grown types of plums. At this time it also became fashionable among the Swedish nobility to import fruit trees from nurseries in Germany and nearby countries on the continent (Nilsson, 1989). However, the outcomes of these imports were hazardous due to slow shipment and lack of knowledge concerning the hardiness of the cultivars. Preserved orchard records written by privy councillor Gustaf Bonde (1682-1764) at Hesselby Castle, Stockholm, show that 30 different plum cultivars were tested (Eneroth, 1866; Nilsson, 1989). In 1729, eight cultivars were in cultivation, among them 'Apricote', 'Reine Claude', 'Mirabelle', three types of egg plums with different characteristics and at least one local cultivar. Following the death of Gustaf Bonde, the orchard declined and according to his son more or less all fruit trees were gone after the harsh winter of 1772 .

Another nobleman with a pomological interest was count Axel Spens (1681-1745) at Grensholm Castle, some 150 $\mathrm{km}$ south of Stockholm. According to Spens' orchard records, four plum cultivars were grafted in 1728 (Jonsson, 1987). Graftwood for 'Apricote' and "Sweet White" was collected from existing trees at Grensholm. Jonsson (1987) assumed that "Sweet White" was synonymous with the cultivar 'Allmänt Gulplommon'. Graftwood for the other two cultivars 'Hungarian Prune' and 'Red Egg Plum' was obtained through contacts in Stockholm, indicating cooperation amongst the fruit growing nobility. In 1780, P. J. Bergius (1730-1790), founder of the Bergius Botanic Garden in Stockholm and a member of the Royal Swedish Academy of Sciences, gave a speech about fruit gardens in which he mentioned eight plum cultivars, among them 'Greengage', 'Mirabelle', 'Yellow Egg Plum' and damson plum (Fries, 1925). Apparently, the assortment of plums had not increased much since the first imports recorded by Gustaf Bonde. It seems like the assortment also remained limited during the first half of the $19^{\text {th }}$ century (Nilsson, 1989). During this period, damson plums and 'Allmänt Gulplommon' still dominated in home gardens. Large fruited cultivars, like 'Reine Claude' and 'Yellow Egg Plum', were only seen in the gardens of larger estates.

Although we still to this day have cultivars with names similar to those mentioned above, we can unfortunately we not be sure that they are identical. Already in the $18^{\text {th }}$ century, there were problems with synonymous names and related mix-ups. In 1866, Eneroth (1866) described the situation as follows: "Completely neglected as the growing of plums is one has occasionally not even names for the plum cultivars. Often one is content with such general descriptions as white plum, blue plum and egg plum with the specification of yellow, red and so on" (pages 80-81). Eneroth himself described 47 plum cultivars. Many of his descriptions are detailed and therefore valuable for the identifica-

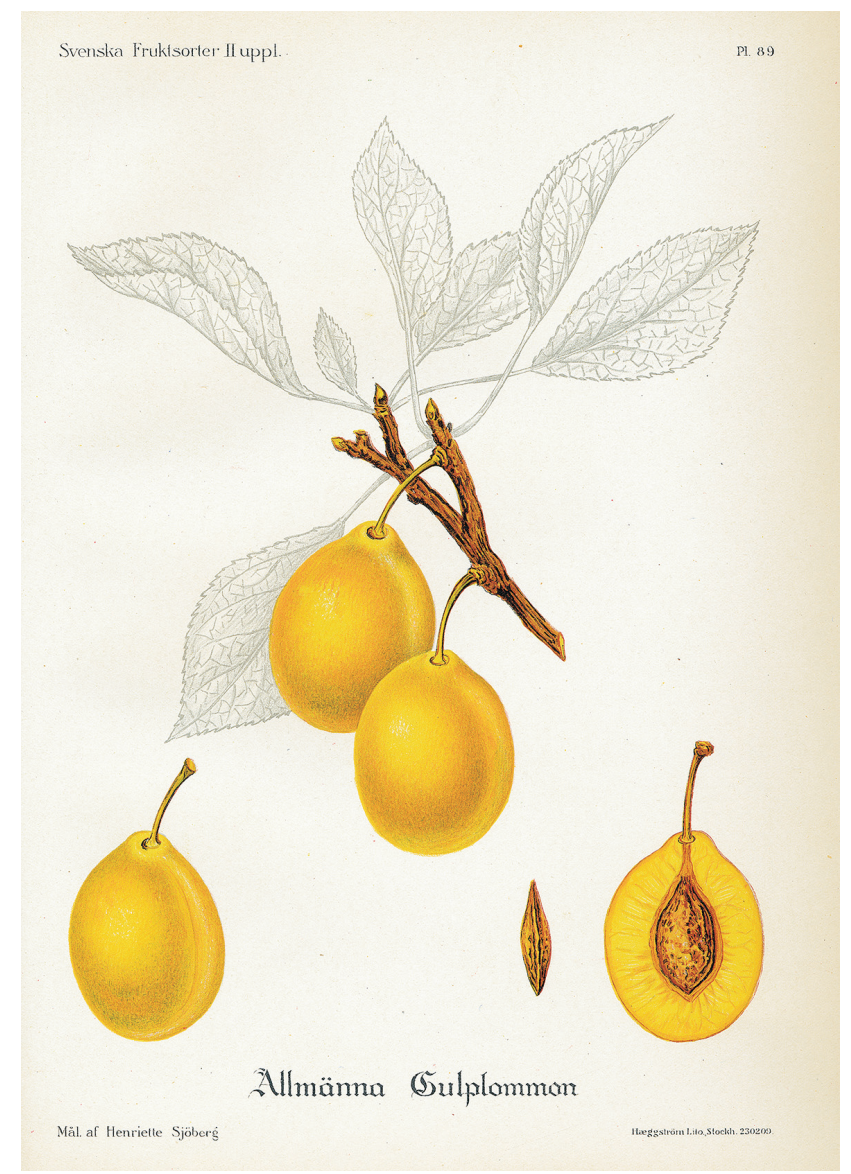

Fig. 1. 'Allmänt Gulplommon' portrayed by artist Henriette Sjöberg (Pihl and Eriksson, 1912).

tion of surviving old cultivars. Starting in 1862, Eneroth imported graftwood from plum cultivars for evaluation in selected orchards. Simultaneously, fruit gardens for cultivar testing were also started by other organisations. Eneroth and Smirnoff (1901) mention that 125 cultivars had been tested at the Experimental Field of the Royal Swedish Academy of Agriculture in Stockholm and that 300 cultivars were evaluated for different purposes at the Institute of Agriculture at Alnarp (south Sweden). According to Nilsson (1989), the cultivars at Alnarp were evaluated for both fresh fruit consumption and dried fruit usage.

\section{DEVELOPMENT OF PLUM PRODUCTION, NURSERY ASSORTMENT, RESEARCH AND BREEDING IN THE $20^{\mathrm{TH}}$ CENTURY}

Official statistics from 1927 show that the number of plum trees in Sweden, counting trees in both commercial orchards and home gardens, were approximately 1 million with an estimated yearly harvest of 6000 tonnes (Sonesson, 1935). These figures remained rather stable until the cold winters of 1939 to 1942 , which reduced the number of trees by 32 \% (Lundin, 1944). During the mid-1950s the number of trees increased to 1.3 million (Nilsson, 1958). Commercial production has always been concentrated in the southern parts of Sweden. In the mid-1950s, the yearly production in commercial orchards was estimated to be 2000 tonnes per 
year (Nilsson 1958). By 2017, the corresponding figure had dropped to 246 tonnes (Anon, 2018).

The traditional way of plum cultivation in Sweden was growing local cultivars on their own roots. Most local plums are either damsons or similar to these. Also, they tend to be hardy and high yielding. 'Mälarplommon' is an example of a local cultivar that has been produced commercially. For many decades, this white yellowish fruit was frequently grown in the Stockholm archipelago and sold in large quantities on markets in the capital (Post, 1927; Hjalmarsson et al., 2008). The production was easy and yield was dependable. There was no need for nurseries and the rootlets were planted densely. The yields were high and harvesting was done by shaking the trees and collecting the fruits from the ground. In the 1920s, 'Mälarplommon' was the dominating commercial cultivar in the Stockholm area and it stayed in production into the 1940s (Post, 1927; Dahl, 1943).

Reimer (1935) and Dahl (1943) studied the plum assortment of 54 nurseries in 1932 and 63 nurseries in 1942. Both studies showed that the ten most propagated cultivars were: 'Victoria', 'Reine Claude d'Oullins', 'The Czar', 'Jefferson', 'Reine Claude Verte', 'Experimentalfältets Sviskon', 'Hackman', 'River's Early Prolific', 'Brignole Violet' and 'Allmänt Gulplommon'. A similar study of 40 nurseries made by Persson in 1983 was reported by Nilsson (1989). At that time 'Reine Claude d'Oullins', 'Victoria', 'The Czar', 'Jefferson', 'Hackman' and 'Allmänt Gulplommon' remained among the top ten, accompanied by 'Kirke's' and the Swedish bred cultivars 'Opal', 'Gilbert' and 'Herman'. In addition, combining the studies we find that the total number of cultivars in the catalogues had declined from 73 in 1932 to 28 in 1983.

The evaluation of cultivars in different experimental collections presumably influenced the assortment in nurseries and orchards. Dahl's pomology 1943 was to a large extent the result of his observations at Alnarp. The activities of the Swedish Association of Pomology (SPF) from 1900 to 1962 were also influential, along with those of the state financed Statens Trädgårdsförsök (ST), which performed experimental research in horticulture from 1938 to 1962. ST reported two plum cultivar and rootstock trials. The first trial was planted in 1939 at Rånna (central Sweden) and the second in 1946 at Alnarp. At Rånna the highest yield was obtained from 'Reine Claude d'Oullins' followed by 'Victoria', 'Rivers Early Prolific' and 'The Czar' (Hintze, 1955). At Alnarp it was found that 'Opal', 'Reine Claude Althans', 'Reine Claude d'Oullins', 'Jefferson' and 'Victoria' were the most suitable for commercial production (Johansson, 1958).

During approximately 30 years following the start in 1923, pollination experiments on plums were carried out at Alnarp (Johansson, 1951). Seeds from crossings were sown out and they resulted in three new cultivars, of which 'Opal' has been the most important. In the early 1940s, breeding programmes with plums started at the Balsgård Fruit Breeding
Institute. The priority of these was to produce improved early ripening cultivars suitable for the Swedish climate (Nybom and Oldén, 1963). This ambition resulted in Balsgård's first plum cultivars 'Gilbert' and 'Herman', of which 'Herman' is the hardiest (Oldén, 1974). During the 1980s and 1990s, production of compact or dwarf cultivars that could be grown on their own roots for usage in dense plantings became the focus for breeding at Balsgård (Trajkovski, 1984). The cultivars 'Madame' (originally 'Madeleine') and 'Violetta' were results of these efforts (Trajkovski and Andersson, 1988; 1992). The overall goals of these breeding programmes were to produce hardy and healthy cultivars with a large span of ripening periods and good commercial qualities.

\section{PLUM CULTIVARS IN THE SWEDISH NATIONAL GENE BANK}

The Swedish National Gene Bank, which is a result of the work at Pom, was officially opened in 2016. Regarding fruit, the main goal is long-term conservation of the Swedish pomological heritage (Hjalmarsson 2003). The conservation effort focuses on so-called mandate cultivars. A mandate cultivar can either be a cultivar of Swedish origin which has been named or spread locally, a cultivar bred and marketed by Swedish breeders or a foreign cultivar with a documented growing tradition in Sweden. The mandate cultivars were primarily selected through literature reviews, drawing heavily on the main Swedish pomology books along with reports and periodicals from SPF, ST, Alnarp and Balsgård. In addition, articles in old horticultural journals, textbooks in pomology and nursery catalogues were important sources of information. The initial list of plum mandate cultivars, which comprised 41 cultivars (Hjalmarsson, 2007), was slightly altered after a national inventory in which Pom asked the public to report their favourite old plums. At present, there are 44 cultivars of dessert and household plums on the list. However, this number may increase somewhat in the future after further evaluations have been made of collected inventory finds.

The Swedish National Gene Bank consists of a central collection of two trees of each cultivar at the Swedish University of Agricultural Sciences in Alnarp along with a twotree back-up system involving local clonal archives. Thus, each plum mandate cultivar will be preserved as four trees - two at Alnarp and two in a local clonal archive. At present, the plum cultivars are dispersed in nine local clonal archives located from southern to central Sweden. The clonal archives are hosted by public institutions like outdoor museums, parks and horticultural schools and as such they are also partners in disseminating information about heirloom cultivars to the public. Each archive has a contract with the Swedish National Gene Bank specifying the cultivars that they are responsible for. In addition, the contract involves a yearly economic compensation for the maintenance of the trees. 
MANDATE CULTIVARS WITH FOREIGN BACKGROUND TRADITIONALLY GROWN IN SWEDEN INCLUDING THEIR OCCURRENCE IN THREE POMOLOGY BOOKS

\begin{tabular}{|c|c|c|c|c|c|c|}
\hline Cultivar name & Country of origin & Known since & Introduction in Sweden & Eneroth 1866 & Dahl 1943 & Nilsson 1989 \\
\hline Reine Claude Althans & Bohemia & $1850 \mathrm{~s}$ & $1880 \mathrm{~s}$ & . & $\mathrm{X}$ & $\mathrm{X}$ \\
\hline Schamals Herbstpflaume & Bohemia & $1840 \mathrm{~s}$ & 1880 & . & $\mathrm{X}$ & . \\
\hline The Czar & England & $1870 \mathrm{~s}$ & before 1910 & . & $\mathrm{X}$ & $\mathrm{X}$ \\
\hline Kirke's & England & $1830 \mathrm{~s}$ & $1850 \mathrm{~s}$ & $\mathrm{X}$ & $\mathrm{X}$ & $\mathrm{X}$ \\
\hline River's Early Prolific & England & $1830 \mathrm{~s}$ & $1870 \mathrm{~s}$ & $\mathrm{X}$ & $\mathrm{X}$ & $\mathrm{X}$ \\
\hline Victoria & England & $1840 \mathrm{~s}$ & before 1886 & . & $\mathrm{X}$ & $\mathrm{X}$ \\
\hline Brignole Violet & France & Old & $1850 \mathrm{~s}$ & $\mathrm{X}$ & $\mathrm{X}$ & $\mathrm{X}$ \\
\hline Bonne de Bry & France & $1820 \mathrm{~s}$ & about 1895 & . & $\mathrm{X}$ & $\mathrm{X}$ \\
\hline Mirabelle de Nancy & France & very old & perhaps 18 th century & . & $\mathrm{X}$ & $\mathrm{X}$ \\
\hline Reine Claude d'Oullins & France & $1860 \mathrm{~s}$ & 1864 & . & $\mathrm{X}$ & $\mathrm{X}$ \\
\hline Reine Claude Verte & France & very old & 18th century & $X$ & $\mathrm{X}$ & $\mathrm{X}$ \\
\hline Ulriksen & uncertain & . & 1873 & . & $\mathrm{X}$ & $\mathrm{X}$ \\
\hline Apricote & uncertain & very old & 18th century & $\mathrm{X}$ & $\mathrm{X}$ & $\mathrm{X}$ \\
\hline Witte Eijerpruim & uncertain & very old & 18th century & $X$ & $\mathrm{X}$ & $X$ \\
\hline Peach & uncertain & Old & 1870 s or earlier & $\mathrm{X}$ & $\mathrm{X}$ & $\mathrm{X}$ \\
\hline Frühe Aprikosenpflaume & uncertain & very old & unknown & . & $\mathrm{X}$ & $\mathrm{X}$ \\
\hline Extra Early Cherry & uncertain & . & $1910 \mathrm{~s}$ & . & $X$ & . \\
\hline Violette Jerusalemspflaume & uncertain & 1820th & . & $\mathrm{X}$ & . & . \\
\hline Kejsarplommon & uncertain & . & . & $\mathrm{X}$ & $\mathrm{X}$ & . \\
\hline Jefferson & US & about 1825 & $1840 \mathrm{~s}$ & $\mathrm{X}$ & $\mathrm{X}$ & $\mathrm{X}$ \\
\hline Washington & US & $1790 \mathrm{~s}$ & $1840 \mathrm{~s}$ & $X$ & $\mathrm{X}$ & $\mathrm{X}$ \\
\hline
\end{tabular}

As shown in Table 1 , there are 21 foreign mandate cultivars. Five of these originate from France, four from England, two from Bohemia and two from the US. Seven cultivars have an uncertain origin but are probably European, although 'Extra Early Cherry' might originate from the US. 'Extra Early Cherry' is also the only cultivar belonging to the species P. cerasifera Ehrh. (Dahl, 1943). It has been suggested that 'Witte Eierpruim' originates from the Netherlands and 'Peach' from either France or England, but this has not been confirmed in the literature (Dahl, 1943). In Sweden, 'Frühe aprikosepflaume' is better known under the local name 'Skånskt Gulplommon' ("Scanian Yellowplum"). This cultivar has been extensively grown on its own roots in the southernmost county of Sweden, where it assumed the same role as 'Allmänt Gulplommon' did in other parts of the country (Nilsson, 1989). The cultivar 'Ulriksen' was imported to Alnarp in 1873 from André Leroy in Angers under the name 'Jaune Hâtive', which turned out to be incorrect (Dahl, 1943). Thus, in 1929 the cultivar was named 'Ulriksen' after the previous head gardener at Alnarp. All the cultivars in Table 1 appear in at least one of the main Swedish pomology books, and 52\% are included in Eneroth (1866), 95\% in Dahl (1943), and $81 \%$ in Nilsson (1989).

Table 2 lists plum cultivars developed by Swedish research institutes and in the following text some of the most important ones are presented more in detail. Experimentalfältets Sviskon' originates from stones sown in 1860 by head gardener Lindgren at the Experimental Field of the Royal Swedish Academy of Agriculture in Stockholm (Dahl,
1943). Supposedly, the stones were from open-pollinated 'Frühe Englische Zwetsche'. Since the 1890s, 'Experimentalfältets Sviskon' has been commonly grown in Sweden, as well as in neighbouring countries. The fruit is of medium size, oval or somewhat egg-shaped. Skin colour is dark-violet. Flesh is yellowish, juicy and tasty. It ripens in September. 'Opal' from Alnarp was obtained from a crossing made in 1925 between 'Reine Claude d'Oullins' and 'Early Favourite' (Johansson, 1948). The fruit is of medium size, in its form resembling 'The Czar'. Skin colour is reddish-violet. Flesh is yellow, juicy sweet and pleasant. It ripens in August and replaced other early ripening cultivars like 'Bonne de Bry' after its introduction on the market in 1948. 'Opal' has had a large impact on the Swedish plum industry as well as being an appreciated cultivar in home gardens. 'Emil' was released in 1978 following the death of Alnarp's plum breeder Emil Johansson, and was named after him (Goldschmidt, 1978). 'Emil' is the result from a crossing between 'Jefferson' and 'Reine Claude Althans' made in 1942. Before its release, 'Emil' was studied in a cultivar trial at Alnarp from 1950 to 1972, where it obtained high scores (Wohlström, 1974). The fruit is oval-roundish with green-yellowish ground colour and red over colour. Flesh is yellow, juicy and good tasting. It ripens two weeks after 'Opal'. Yield is high and there is no need for thinning. Fruit weights around $40 \mathrm{~g}$ are not unusual. 'Emil' has recently been suggested as a cultivar suitable for ecological production (Tahir, 2014).

'Herman' from Balsgård was obtained through a crossing between 'The Czar' and 'Ruth Gerstetter' in 1952 (Oldén, 
MANDATE CULTIVARS DEVELOPED BY SWEDISH BREEDERS

\begin{tabular}{|c|c|c|c|}
\hline Cultivar name & Release year & Breeding institute & Parentage \\
\hline $\begin{array}{l}\text { Experimentalfältets } \\
\text { Sviskon }\end{array}$ & 1890 & Royal Swedish Academy of Agriculture, Stockholm & seedling from Frühe Englische Zwetsche \\
\hline Opal & 1948 & Statens Trädgårdsförsök, Alnarp & Reine Claude d'Oullins $\times$ Early Favourite \\
\hline Ariel & 1960 & Statens Trädgårdsförsök, Alnarp & Autumn Compot $\times$ Reine Claude Althans \\
\hline Emil & 1978 & Swedish University of Agricultural Sciences, Alnarp & Jefferson $\times$ Reine Claude Althans \\
\hline Gilbert & 1968 & Fruit Breeding Institute, Balsgård & Ontario $\times$ Ruth Gerstetter \\
\hline Herman & 1974 & Agricultural College of Sweden, Balsgård & Czar $\times$ Ruth Gerstetter \\
\hline Ive & 1977 & Swedish University of Agricultural Sciences, Balsgård & seedling from Reine Claude Althans \\
\hline Meritare & 1985 & Swedish University of Agricultural Sciences, Balsgård & Opal $\times$ Ontario \\
\hline Madame & 1988 & Swedish University of Agricultural Sciences, Balsgård & Hackman $\times$ Victoria \\
\hline Jubileum & 1988 & Swedish University of Agricultural Sciences, Balsgård & Giant $\times$ Yakima \\
\hline Herkules & 1991 & Swedish University of Agricultural Sciences, Balsgård & Ontario $\times$ Formosa \\
\hline Anita & 1994 & Swedish University of Agricultural Sciences, Balsgård & Laxton's Early $\times$ Ruth Gerstetter \\
\hline
\end{tabular}

1974). It is named after Professor Herman Nilsson-Ehle, who was one of the initiators of the Fruit Breeding Institute at Balsgård. The fruit is of medium size and oval. Skin colour is blue-violet and flesh is yellow green with slightly acidic flavour. It ripens at the turn of the month July/August. As an early ripening and hardy cultivar, 'Herman' became important for the Swedish plum industry. 'Jubileum' was developed through a crossing between 'Giant' and 'Yakima' (Trajkovski and Andersson, 1990). The fruit is oblong, purple and large, weighing about $70 \mathrm{~g}$. Flesh is firm, both sweet and acidic in taste. It ripens just before 'Victoria', and has replaced this cultivar in commercial orchards. 'Jubileum' is still recommended to Swedish orchardists (Tahir, 2015).

Table 3 comprises ten local cultivars that are presumed to be of Swedish origin. Most likely, a majority of these were originally grown on their own roots. In the literature some of them are sometimes referred to as damson plum $P$. domestica ssp. insititia (L.) Poir (Nilsson, 1958; 1989). Also, a DNA-based study in 2015 (Nybom et al., 2015) indicated close relatedness between damson plums and the local cultivars 'Mälarplommon' and 'Tunaplommon'. Four of the cultivars on the list are not described in any of the main Swedish pomology books. 'Elam' from the 1990s is too young, whereas 'Hagbyholms sviskon' is instead presented in the work of Pihl and Eriksson (1912). 'Reine Claude Bålnäs', a local variation of 'Reine Claude', is known at least since the 1950s when it was tested for winter hardiness at Balsgård (Oldén, 1956). Finally, 'Skårbyplommon' was not noted in the literature until it was identified in the national inventory.

'Allmänt Gulplommon' is considered to be the oldest of the cultivars in this table, and perhaps it was brought to Sweden already during medieval times (Nilsson, 1989). 'Allmänt Gulplommon' also occurs under the names 'Vitplommon' ('White Plum') and 'Äggplommon' ('Egg Plum'). The fruit is of medium size, egg-shaped and yellow. Flesh is rather coarse, white-yellowish and sweet with a
Table 3

MANDATE CULTIVARS CATEGORIZED AS SWEDISH LOCAL CULTIVARS INCLUDING THEIR OCCURRENCE IN THREE POMOLOGY BOOKS

\begin{tabular}{|c|c|c|c|c|}
\hline Cultivar name & Known since & $\begin{array}{c}\text { Eneroth } \\
1866\end{array}$ & $\begin{array}{c}\text { Dahl } \\
1943\end{array}$ & $\begin{array}{c}\text { Nilsson } \\
1989 \\
\end{array}$ \\
\hline Allmänt Gulplommon & very old & $X$ & $\mathrm{X}$ & $\mathrm{X}$ \\
\hline Elam & early 1990s & . & . & . \\
\hline Hackman & before 1837 & $\mathrm{X}$ & $\mathrm{X}$ & $\mathrm{X}$ \\
\hline Hagbyholms Sviskon & before 1860 & . & . & . \\
\hline Karlslundsplommon & old & . & . & $X$ \\
\hline Mälarplommon & old & . & $\mathrm{X}$ & $\mathrm{X}$ \\
\hline Reine Claude Bålnäs & before $1950 \mathrm{~s}$ & . & . & . \\
\hline Skårbyplommon & about 1900 & . & . & . \\
\hline Tunaplommon & old & . & . & $\mathrm{X}$ \\
\hline $\begin{array}{l}\text { Västmanlands } \\
\text { Rödplommon }\end{array}$ & old & $\mathrm{X}$ & . & $\mathrm{X}$ \\
\hline
\end{tabular}

pleasant taste. It ripens at the end of September. According to Eneroth (1866), 'Allmänt Gulplommon' was the most common plum in Sweden during the $19^{\text {th }}$ century. Another cultivar that has been grown for long a time is 'Hackman' (Fig. 2), named after the Swedish priest Gustaf Hackman (1748-1806). The first written account of 'Hackman' is found in the 1837 nursery catalogue from the Löberöd Estate (south Sweden). However, the origin of 'Hackman' remains unknown (Dahl, 1931). The fruit is rather large, oval and yellowish green (Dahl, 1943). Flesh is somewhat coarse, juicy, yellow-green, sweet and slightly acidic with an attractive flavour. 'Hackman' ripens in September and has been grown not only in Sweden, but also in Denmark and Norway.

'Skårbyplommon' is an example of a local cultivar from the turn of the $18^{\text {th }} / 19^{\text {th }}$ centuries. According to the story told to Poms during the national inventory, a family on a small farm near Kungsbacka on the west coast of Sweden received plum stones from the US sent by a Swedish emi- 


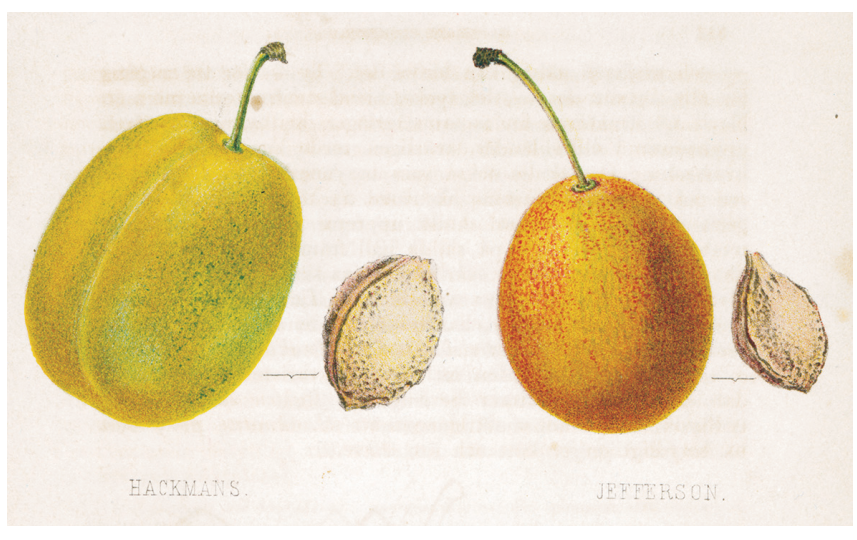

Fig. 2. 'Hackman' and 'Jefferson' portrayed by artist Bertha Wernquist (Eneroth, 1866).

grant who had tasted wonderful plums in his new home country. Those stones were sown out and one of them resulted in 'Skårbyplommon'. The fruit is rather small in size, prune-like and dark reddish. Flesh is yellow, juicy and tasty. 'Elam' is another local cultivar but of younger date. It was noticed as a young seedling under an old plum tree growing on the small farm of the family Elamsson in Skoghall (central Sweden). In the early 1990s, 'Elam' was marketed by a local nursery. The fruit is rather large, yellow and has an attractive taste (Hjalmarsson, 2014).

\section{SUMMARY}

For hundreds of years, plum trees have been common on the Swedish countryside and in urban gardens. In the old times, small-fruited plums grown on their own roots gave fruits and occasionally income to families. They were easy to grow, high yielding and had multipurpose use. Sometimes they were planted as farmhouse avenues (Reimer, 1933). The importance of small-fruited plums remained until the 1950s. Large-fruited plum cultivars from continental Europe were imported by the nobility already during the $18^{\text {th }}$ century, but most of these did not survive in the Scandinavian climate. The next wave of imports occurred during the second half of the $19^{\text {th }}$ century when there was a broader interest for pomology in society at large. Olof Eneroth was supported by the government in publishing his pomology and the first commercial orchards developed. During the $20^{\text {th }}$ century, the fruit industry grew and organisations for experimental research developed. Cultivar trials made it easier for growers and private persons to choose cultivars fitting their needs. In the 1930s, there were about 70 cultivars marketed by Swedish nurseries, but already at the end of the $20^{\text {th }}$ century the assortment had declined drastically. Today the Swedish National Gene Bank preserves some 45 plum mandate cultivars. In the future it will be possible for researchers, breeders, nurserymen, orchardists, and others with an interest in pomology to order graftwood. In addition, the Swedish University of Agricultural Sciences owns the trade mark "Green heritage" whereby the nurseries can market the mandate cultivars to the general public. To date, ten plum mandate cultivars are marketed as "Green heritage".

\section{REFERENCES}

Anderberg, A., Anderberg, A.-L. (2017). Den virtuella floran [The virtual flora]. Available from:

http://linnaeus.nrm.se/flora/di/rosa/prunu/prundom/htlm (accessed 29.09.2018) (in Swedish).

Anonymous (2018). Jordbruksstatistik sammanställning 2018 [Agricultural Statistics 2018]. Official Statistics of Sweden. Statistics Sweden. Available from: www.scb.se/publikation/35150 (accessed 29.09.2018) (in Swedish).

Dahl, C. G. (1931). Efter vem har Hackmanplommonet fått sitt namn? [After whom was the Hackman plum named?]. Svensk Pomologisk Förenings Arsskrift, 32, 115 (in Swedish).

Dahl, C. G. (1943). Pomologi, beskrivningar över de viktigaste i Sverige odlade fruktsorterna. Del 2. Päron och plommon [Pomology, descriptions over the most important fruits cultivated in Sweden. Part 2. Pears and plums]. Bonnier, Stockholm. 390 pp. (in Swedish).

Eneroth, O. (1866). Handbok $i$ svensk pomologi [Handbook in Swedish Pomology]. Norstedt, Stockholm. 403 pp. (in Swedish).

Eneroth, O., Smirnoff A. (1901). Handbok i svensk pomologi [Handbook in Swedish Pomology]. Norstedt, Stockholm. 336 pp. (in Swedish).

Fries, R. E. (1925). P. J. Bergius och hans betydelse för den svenska hortikulturen [P. J. Bergius and his importance for Swedish horticulture]. Svensk Pomologisk Arsskrift, 26, 141-162 (in Swedish).

Goldschmidt, E. (1978). Plommonsorten Emil [Plum cultivar Emil]. SYR-inf, No. 1, 9-10 (in Swedish).

Hintze, S. (1955). Sort- och grundstamsförsök med plommon vid Rånna 1939-1954 [Cultivar and rootstock trial with plums at Rånna 1939-1954]. Medd. fr Statens trädgårdsförsök, Nr. 92,7 (in Swedish).

Hjalmarsson, I. (2003). Conservation of Swedish fruit, berry and nut varieties. Nordiske genresursser, 2 (1), 12.

Hjalmarsson, I. (ed.) (2007). Här bevaras våra svenska fruktsorter [Where Swedish fruit cultivars are preserved]. CBMs skriftserie 16. CBM Swedish Biodiversity Centre. 43 pp. (in Swedish).

Hjalmarsson, I. (2014). Plommon Prunus domestica 'Elam' [Plum Prunus domestica 'Elam']. Tidning för Hushållningssällskapen i Jönköping, Västra Götaland och Värmland, Nr. 4, 33 (in Swedish).

Hjalmarsson, I., Trajkovski, V., Wallace, B. (2008). Adaption of foreign plum and cherry varieties in Sweden. In: Proceedings of International Scientific Conference. Sustainable Fruit Growing: From Plant to Product. Jürmala-Dobele, May 28-31, 2008. Latvia State Institute of FruitGrowing, pp. 141-148.

Hjelmqvist, H. (1991). Några Trädgårdsväxter från Lunds medeltid [Some horticultural plants from medieval Lund]. Svensk Bot. Tidskr., 85 (4), 225-248 (in Swedish).

Johansson, E. (1948). Opal — en ny svensk plommonsort [Opal - a new Swedish plum cultivar]. Statens trädgårdsförsöks särtr., Nr 14, 6 (in Swedish).

Johansson, E. (1951). Plommon [Plums]. In: Åkesson, Å., Nilsson, F., Sylvén, N., Fröier, K. (eds.). Svensk växtförädling del II. Natur och Kultur, Stockholm, pp. 74-85 (in Swedish).

Johansson, E. (1958). Sort- och grundstamsförsök med plommon vid Alnarp 1943-1956 [Cultivar and rootstock trials with plums at Alnarp 1943-1946]. Medd. fr Statens trädgårdsförsök, Nr. 108, 20 (in Swedish).

Jonsson, M. (1987). Numer-bock uppå träna. Sortiment $i$ en fruktträdgård 1728 [Number book of the trees. Assortment in a fruit garden 1728]. Lustgården, 68 (1), 5-26 (in Swedish).

Lundin, Y. (1944). Landets bestånd av fruktträd och bärbuskar [The number of fruit trees and berry bushes in the country]. Svensk Pomologisk Förenings Arsskrift, 45, 119-122 (in Swedish).

Nilsson, A, (1989). Våra päron-, plommon- och körsbärssorter, deras historia, egenskaper och kännetecken [Our Pear, Plum and Cherry Cultivars, Their History, Traits and Identifiers]. Karlebo, Stockholm. 370 pp. (in Swedish). 
Nilsson, F. (1958). Odling av frukt och bär [Cultivation of Fruit and Berry]. Saxon \& Lindström, Stockholm. 296 pp. (in Swedish).

Nybom N., Oldén E. J. (1963). Växtförädlingarbetena vid Balsgård, förutsättningar och resultat [Plant breeding work at Balsgård, background and results]. In: Fernqvistm I., Lammm R. (eds.). Satens trädgårdsförsök 25 år. Kristianstad, pp. 74-81 (in Swedish).

Nybom, H., Sehic, J., Gasi, F. (2015). 'Svenska' plommon på Balsgård ['Swedish' plums at Balsgård]. Swedish Univ. Agr. Sci. LTV-fakultetens faktablad (Alnarp), 2015, No. 5. Available from: https://pub.epsilon.slu.se/11837 (accessed 29.09.2018) (in Swedish).

Oldén, E. J. (1956). Vinterhärdighet hos plommon [Winter hardiness in plums]. Svensk Pomologisk Förenings Arsskrift, 57, 89-112 (in Swedish).

Oldén, E. J. (1974). Herman - en ny plommonsort från Balsgård [Herman — a new plum cultivar from Balsgård]. Särtryck ur SYR-Inf., (1). 3 pp. (in Swedish).

Pihl, A., Eriksson J. (1912). Svenska fruktsorter [Swedish Fruit Cultivars]. Norstedt, Stockholm. 404 pp. (in Swedish).

Post, A. von. (1927). Litet om rotäkta plommon [Something on plums on their own roots]. Svensk Pomologisk Förenings Arsskrift, 28, 25-30 (in Swedish).

Reimer, C. (1933). Något om plommonodling [Some words about plum cultivation]. Svensk Pomologisk Förenings Arsskrift, 34, 249-259 (in Swedish).

Reimer, C. (1935). Plantskoleskötselns omfattning i Sverige år 1932 [The extent of the nursery industry in Sweden 1932]. In: Sonesson, N. (Ed.). Trädgårdsodlingen $i$ Sverige. Saxon \& Lindström, Stockholm, pp. 141-164 (in Swedish).
Sonesson, N. (1935). Försök till beräkning av trädgårdsodlingens produktionsvolym i Sverige [An attempt to estimate the production volume of Swedish horticulture]. In: Sonesson, N. (Ed.). Trädgårdsodlingen $i$ Sverige. Saxon \& Lindström, Stockholm, pp. 189-203 (in Swedish).

Tahir, I. (2014). Fruktodling och efterskördbehandling [Fruit production and post harvest]. Vision Syd, Växjö. 291 pp. (in Swedish).

Tahir, I. (2015). Modern plommonodling i Sverige [Modern plum cultivation in Sweden]. Swedish Univ. Agr. Sci. LTV-fakultetens faktablad (Alnarp). 2015, 36. Available from: https://pub.epsilon.slu.se/12914 (accessed 29.09.2018) (in Swedish).

Trajkovski, V. (1984). Växtförädling av stenfrukter [Stone fruit breeding]. Report 1982-1983, Swed. Univ. Agr. Sci., Div. Fruit Breed., Balsgård, 21-26 (in Swedish).

Trajkovski, V., Andersson, G. (1988). Växtförädling av stenfrukter [Stone fruit breeding]. Report 1986-1987, Swed. Univ. Agr. Sci., Div. Fruit Breed., Balsgård, 16-23 (in Swedish).

Trajkovski, V., Andersson, G. (1990). Stone fruit breeding. Summary. Report 1988-1989, Swedish Univ. Agr. Sci., Balsgård, Dep. Hort. Plant Breed, 25-26.

Trajkovski, V., Andersson, G. (1992). Stone fruit breeding. Summary. Report 1990-1991, Swedish Univ. Agr. Sci., Balsgård, Dep. Hort. Plant Breed, 30-31.

Westwood, M. N. (1993). Temperate Zone Pomology. Timber Press. Portland, Oregon. 523 pp.

Wohlström, C. (1974). Sort- och grundstamsförsök med plommon 1950-72 [Cultivar and Rootstock Trial With Plums 1950-72]. Agr. College of Sweden. Serie A. 218. Uppsala. 23 pp. (in Swedish).

Received 28 January 2019

Accepted in the final form 24 March 2019

\section{PLŪMJU ŠĶIRNES ZVIEDRIJĀ: VĒSTURE UN SAGLABĀŠANA IZMANTOŠANAI NĀKOTNĒ}

Rakstā atspoguḷota plūmju audzēšanas un šḳirṇu vēsture Zviedrijā ar mērḳi aprakstît škirṇu mantojumu un izskaidrot, kā tās tiek saglabātas Zviedrijas Nacionālajā gēnu bankā. Komerciāla plūmju audzēšana Zviedrijā sākās ap 1890. gadu, un sākotnēji tā balstîjās uz sīkaugḷu vietējo plūmju patsakṇiem. 20. gadsimta 50. gadu vidū plūmju ražošana Zviedrijā sasniedza apmēram 2000 tonnas gadā. Kopš 80. gadu vidus ražošana samazinājās un šobrīd ir tikai 250 tonnas gadā. Darbs pie škirņu mantojuma saglabāšanas sākās ar nacionālo inventarizāciju 2005. gadā. Kopš 2012. gada tā sauktās mandātškirnes ir iestādītas Zviedrijas Nacionālajā gēnu bankā Alnarpā. Šobrīd tajā ir pārstāvētas 45 plūmju škirnes — divi koki no katras vietējā klonu arhīvā. 